\title{
A review of the National Social Security Fund in China
}

\author{
Stuart Leckie* \\ is based in Hong Kong and advises on investments and pensions in Asia. He is the author of the books Pension Funds in China and Investment \\ Funds in China. He is the Founding Chairman of the Hong Kong Retirement Schemes Association, and acts as a trustee of a number of retirement \\ schemes. He worked in life insurance in the UK before moving to Hong Kong in 1979, serving as the Chairman of Watson Wyatt in Asia-Pacific and as \\ Chairman of Fidelity Investments, Asia-Pacific. He has advised the Chinese Government on pensions reform and is also significantly involved in the \\ development of stock market indices in Asia. He was the President of the Actuarial Society of Hong Kong (1981 and 1999) and was the first Chairman \\ of the International Actuarial Association's China Committee. In addition, he has advised the Hong Kong Government on the establishment of the \\ Mandatory Provident Fund, has served on various committees in Hong Kong's Securities and Futures Commission, and was a Director of Exchange \\ Fund Investment Limited, which launched the highly successful Tracker Fund.
}

\section{Ning Pan}

is a senior consultant and director of research at Stirling Finance. She works with international asset management firms and service providers on strategic market entry and business development projects in China. Prior to joining Stirling Finance, she worked with Deutsche Bank in New York in its debt capital markets and interest rate derivatives teams. She had also worked as a director with Pacific Strategy Group in Beijing and Hong Kong She obtained a law degree from Nanjing University in China and an MBA from the University of Virginia, USA.

\begin{abstract}
The National Social Security Fund (NSSF) is a strategic reserve fund set up by the Chinese government to help with the looming pension crisis in the country. Since its inception in 2000, it has grown significantly in size, stature and influence, and has become China's no. 1 institutional investor. This paper provides an overview of the NSSF's background, sources of assets and investment activities including its overseas investment initiatives. It also discusses some design and governance issues at the Fund, as well as their potential ramifications.
\end{abstract}

Pensions (2006) 12, 88-97. doi:10.1057/palgrave.pm.5950046

Keywords: China, pensions, investments, NSSF, governance, social security

\section{The looming pension crisis in China}

China faces a looming crisis to provide old-age pensions for its $1.3 \mathrm{bn}$ citizens. The one-child policy implemented since the late 1970s, combined with improved longevity, means that the population is ageing at a rapid speed.

According to data from the UN Population Division, the old age dependency ratio (defined as the number of people aged between 15 and 59 to the number of people aged 60 and above) was 6.2 in 2005 but will rapidly decline to 2.0 by $2040{ }^{1}$

*Correspondence: Stuart Leckie, Stirling Finance Limited, 2202 Tower 2, Lippo Centre, 89 Queensway, Hong Kong, PR China

Tel: +85221479109

Fax: +852 2147-2822

Email: stuart.leckie@stirlingfinance.com
The Chinese government, hoping to build a sustainable pension system, started to implement reforms in the 1990s with the following objectives:

(1) to shift the burden of pension provision from the state only, to be shared by the state, employers and employees;

(2) to move from PAYG financing to a combination of PAYG and funded systems;

(3) to encourage the development of private sector pensions;

(4) to expand pension coverage to all urban workers.

After a series of new regulations, pilot programmes and revisions, the current Chinese pension model is a three-pillar pension system 
broadly in line with the World Bank's multi-pillar model. ${ }^{2}$ The new Chinese pension system, which applies to the urban sector but not the rural community, now includes:

- Pillar Ia - a basic state pension provided through mandatory contributions by employers. Any excess of contributions over benefit payments under Pillar Ia are pooled together at the provincial level and administered by the provincial social security bureaus. Urban retirees will receive about 30 per cent of the local average wage after a working lifetime.

- Pillar Ib - a mandatory individual system funded by employees contributing 8 per cent of their monthly salary. The amount is accumulated in individual accounts earning interest and cannot be accessed until retirement. These assets are also administered by the provincial social security bureaus.

- Pillar II — also known as 'Enterprise Annuities' (EA), which are voluntary defined contribution retirement plans set up by eligible employers. These plans are provided through trustees, administrators, investment managers and custodians approved by the Ministry of Labour and Social Security (MoLSS).

- Pillar III - Various other types of voluntary schemes set up by employers which do not conform to the EA format.

Given the historical pension burdens, however, accumulated over the decades of the communist economy, as well as the rapidly deteriorating demographics, these reforms, even when fully implemented, may prove inadequate. A World Bank study estimates that under a baseline scenario with the current pension system, China's implicit pension debt amounts to 141 per cent of GDP, and the financing gap is as much as 95 per cent of GDP. ${ }^{3}$

The vulnerability of the system was keenly felt in the late 1990s and early 2000s, leading to some loss of confidence among many Chinese. Even though the regulations at the time clearly stated that Pillar Ia and Pillar Ib assets were to be segregated from each other, many provinces, facing huge benefit payouts and insufficient Pillar Ia contributions, decided to conveniently channel Pillar Ib money paying Pillar Ia benefits, resulting in a high number of 'empty' individual accounts. The problem was most severe in the Northeast provinces of Liaoning, Jilin and Heilongjiang, where the heavy concentration of unprofitable state-owned enterprises meant the provinces had significant difficulties to collect Pillar Ia contributions yet had to pay out significant pension benefits.

Fearing potential social unrest, the Chinese central government had to step in to support the provinces. New rules were issued to redesign contribution rates for Pillars $\mathrm{Ia}$ and $\mathrm{Ib}$ and to reinforce the segregation of the two; pilot programmes were launched in Liaoning and later in Jilin and Heilongjiang to test run the new rules; and the troubled provinces were rumoured to be given relief through reduced taxes from the central government to tide over the difficulties. Last but not least, a reserve fund at the national level that could bail out potential provincial pension defaults - the National Social Security Fund (NSSF), was created.

\section{The establishment and the administration of NSSF $^{4}$}

In late 2000, aware of the looming pension difficulties at the provincial level and concerned about the demographics, the Chinese government established the NSSF as 'a strategic reserve fund' and a 'solution to the problem of ageing'. The National Council for Social Security Fund (NCSSF), a ministerial level entity directly reporting to the State Council, was simultaneously created to operate the Fund. The NCSSF is charged with a range of responsibilities that include:

- Administer the assets of the NSSF.

- Formulate and implement the NSSF's investment strategies.

- Select fund managers and custodians for the NSSF assets, and monitor their performance. To the extent allowed by regulations, directly invest the NSSF's assets. 
- Provide financial management and accounts for the NSSF, including the preparation of periodic financial statements and accounting reports.

- Regularly disclose to the public the financial conditions of the NSSF, including assets, returns, cash flows, etc.

- Distribute funds according to directives jointly formed by the Ministry of Finance (MoF) and the MoLSS.

- Undertake other duties assigned by the State Council.

The NCSSF comprises 17 executive board members. It is led by a chairman and three vice chairmen, all appointed directly by the State Council. The executive board oversees seven permanent departments that run the day-to-day operations of the NSSF. In addition to permanent departments, the NCSSF also leads three nonpermanent committees in charge of investment manager/custodian selection, investment decisions and risk management.

It is interesting to note that many of the NCSSF officials have strong ties with or a background in key government departments including the MoF, the MoLSS and the China Securities Regulatory Commission (CSRC). For instance, chairman Xiang Huaicheng served as Minster of Finance from 1998 to 2003. Similarly, vice chairman Gao Xiqing, a western-educated lawyer with Wall Street experience, was previously a top official at the CSRC. Liu Yongfu, Vice Minister of MoLSS, is serving as an NCSSF executive board member. The recruitment of senior officials from other agencies is a reflection of the political reality that the NSSF has multiple stakeholders, and that the smooth functioning of the NSSF will require understanding, coordination and compromise among these various agencies.

\section{NSSF sources of assets}

By law, the assets of the NSSF come from four sources: ${ }^{5}$

(1) Funds allocated from the central government's budget.
(2) Capital and equity assets derived from stateowned enterprise share sales.

(3) Other means approved by the State Council (in practice, this refers to state lottery proceeds, as well as funds obtained through a securities repo programme).

(4) Investment income.

Funds allocated from the central government's budget have historically been the largest source of asset accretion for the NSSF. During the past 5 years however, the NSSF sources of funds have become increasingly diversified, and the proportion of monies from state allocation has been in decline from 100 per cent of the NSSF's net addition to assets in 2000 to about 25 per cent in 2005. Other sources of assets, especially capital and equity assets derived from StateOwned Enterprise (SOE) share sales plus investment income, have been increasing in proportion.

'Capital and equity assets derived from SOE share sales' refers to a proportion of the Initial Public Offering (IPO) proceeds arising from the public offering of SOEs. According to a State Council Regulation issued in 2001 entitled 'Provisional Measures for Raising Funds for NSSF from Divestiture of SOE Assets', Chinese state-owned companies must contribute 10 per cent of their IPO proceeds to the NSSF at the time of their public offerings. This is essentially a form of taxation on IPO proceeds earmarked for the NSSF. The policy was originally applied to both domestic and international offerings, but it has been

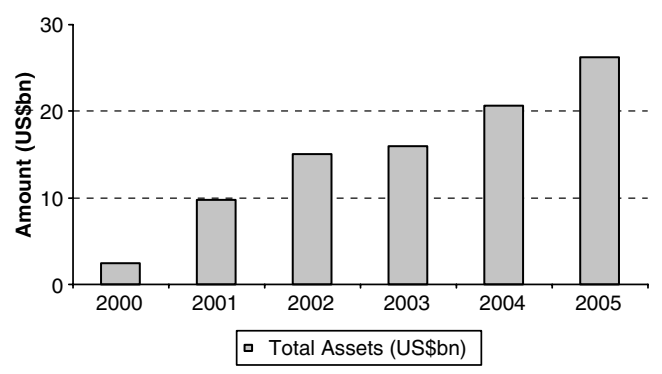

Figure 1: NSSF total assets at year end. Source: NSSF annual reports. Currency conversion at year-end exchange rates. 


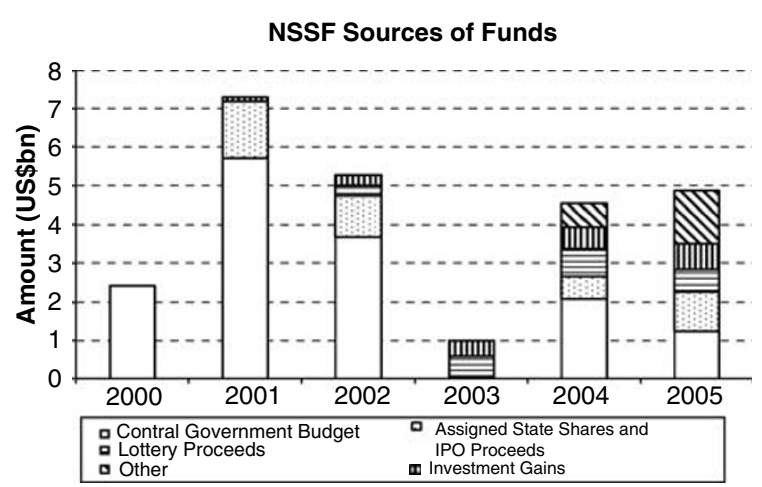

Figure 2: NSSF sources of assets.

Source: NSSF annual reports. Currency conversion at yearend exchange rates. Gain/loss due to currency movements is ignored.

suspended for domestic offerings since June 2002 , as the Chinese equity market went through a prolonged bear-market (2001-2005) with 'the IPO tax' taking part of the blame. Since June 2002, assets from this source have come only from overseas listings of Chinese companies. ${ }^{6}$ In 2005, the IPO proceeds of SOEs were the second largest source of funds, constituting 23 per cent of the net addition in assets (Figures 1 and 2).

Within a short period of time, the NSSF assets had grown to approximately US $\$ 26 \mathrm{bn}$ by the end of 2005, making the NSSF the biggest institutional investor in China. (China's investments funds industry had approximately US\$60bn of AUM at the end of 2005, according to Stirling Finance estimates.) The NSSF is now seeking to increase its assets five-fold from US $\$ 25$ bn in 2005 to US $\$ 125$ bn by 2008 , an ambitious target unless it can secure increased funding as well as higher investment returns. An enhanced long-term stable funding strategy for the NSSF, however, still needs to be clarified. After pouring in approximately US $\$ 12 \mathrm{bn}$ from 2000 to 2002, the MoF did not allocate any funds from the fiscal budget to the NSSF in 2003; and allocations in 2004 and 2005 fell significantly short of 2000-2002 levels. In addition, the State Council's previous decision to suspend the domestic 'IPO tax' due to poor stock market conditions also reflects the political pressures that can disrupt a long-term strategic programme.

\section{The investments of NSSF}

\section{Regulatory framework for investments}

The investment activities of the NSSF are governed by two sets of rules:

(1) 'The Preliminary Rules on the Administration of the Investments of the NSSF' (The Preliminary Rules) issued jointly by MoLSS and MoF in December 2001.

(2) 'The Preliminary Rules on the Management of Overseas Investments of the NSSF' (The Preliminary Rules on Overseas Investments) issued jointly by MoLSS, MoF and State Administration of Foreign Exchange (SAFE) in March 2006.

Under the Preliminary Rules, the NCSSF is charged with the responsibility for developing the NSSF's investment strategies and organising the implementation of these strategies. The Preliminary Rules states that the NSSF must stick to the principle of 'achieving value appreciation on the basis of ensuring the safety and liquidity of the assets' in its investments.

The NSSF can either directly invest the assets, or appoint licensed investment managers. If the NSSF, however, chooses to directly invest the assets, it can only invest in bank deposits or government bonds. For all other types of investments, the NSSF needs to appoint fund managers and custodians approved by the MoLSS. The Preliminary Rules also details criteria, roles and responsibilities for investment managers and custodians for the NSSF.

According to the Preliminary Rules, no less than 50 per cent of the NSSF assets must be invested in bank deposits and government bonds, no more than 10 per cent in corporate bonds, and no more than 40 per cent in equities and funds. The NSSF often refers to these categories of investments as 'low-risk', 'comparatively low risk' and 'high risk high return' investments respectively.

The Preliminary Rules on Overseas Investments specifies the eligibility criteria of international fund managers and custodian banks in respect of the NSSF's foreign investments. 
Table 1: Investment allocation of NSSF assets

\begin{tabular}{|c|c|c|c|c|c|c|}
\hline Year end & 2000 & 2001 & 2002 & 2003 & 2004 & 2005 \\
\hline Total Assets (USD billion) & 2.4 & 9.7 & 15.0 & 16.0 & 20.7 & 26.2 \\
\hline Self Managed Assets (\%) & 100.0 & 100.0 & 100.0 & 75.9 & 64.2 & 65.5 \\
\hline Bank Deposits (\%) & & 64.6 & 75.6 & 45.3 & 38.3 & 48.2 \\
\hline Interest Receivables (\%) & 0.1 & 0.3 & 0.8 & 1.1 & 0.9 & 0.8 \\
\hline ST Notes (\%) & & & & 0.8 & 0.1 & 0.1 \\
\hline LT bonds with < 1 year maturity (\%) & & & & 11.6 & 2.5 & 2.0 \\
\hline Long-term bonds (\%) & 99.9 & 33.6 & 22.5 & 17.1 & 15.6 & 6.0 \\
\hline Index products (\%) & & & & & & 1.7 \\
\hline Securitisation products (\%) & & & & & & 0.2 \\
\hline Direct equity investments (\%) & & & & & 6.8 & 6.5 \\
\hline Sinopec IPO shares (\%) & & 1.6 & 1.0 & & & \\
\hline Assets under third party management (\%) & 0.0 & 0.0 & 0.0 & 24.1 & 35.8 & 34.5 \\
\hline
\end{tabular}

Source: NSSF annual reports. Currency conversion at year-end exchange rates.

\section{Appointment of domestic fund managers}

From 2001 to 2003, except for a one-time purchase of about RMB1.3b (Chinese renminbi currency, also known as yuan) (US\$153m) of Sinopec IPO shares in 2001, most of the NSSF's funds were self-managed and kept in the form of cash and government bonds. Given China's low interest environment, returns on these investments were very modest, hovering between 2 and 3 per cent. ${ }^{7}$ Although these returns beat price inflation during that period of time, they were significantly less than China's salary inflation rates. A cash-and-government-bond-only investment strategy is also inappropriate for a long-term pension fund in a rapidly growing economy (Figure 3).

The situation started to change in 2003, when the NSSF appointed six domestic fund managers for domestic equity and bond mandates. The managers included Boshi (now re-named Bosera), Changsheng, Huaxia, Harvest, Penghua and Southern, all considered among the best in the Chinese fund management industry. The NSSF 2003 annual report indicates that the amount of assets mandated to these managers was RMB32bn (US $\$ 4 \mathrm{bn}$ ), or approximately 24 per cent of the total assets, at the end of the year.

In 2004, the NSSF further appointed 4 additional managers - CICC; China Merchants; E-fund and Guotai, for 'stable allocation' mandates. By the end of 2005, the amount of assets mandated to domestic fund managers had increased to RMB73bn (USD9bn), or approximately 34 per cent of the NSSF's total assets (Table 1).

Assuming half of these mandates are invested in equities and factoring in pre-IPO private equity investments and other direct equity investments, the NSSF's investments in equities exceeded 20 per cent of its total assets by the end of 2005 .

During the first three-quarters of 2006, the NSSF has significantly increased its equities allocations. As of the end of September 2006, approximately 23.5 per cent of NSSF assets were invested in listed shares while another 13.7 per cent in direct equity, bringing the total equities investment to 37.2 per cent, approaching the statutory 40 per cent limit. For the remaining assets, 54.5 per cent were invested in bonds and 8.3 per cent in cash. ${ }^{8}$

The declining equity market in China during 2004 and the first part of 2005 did not bode well for the NSSF's debut equity investments. The NSSF's overall realised returns in 2004 and 2005 were only slightly above 3 per cent. The situation is bound to change in 2006 due to the dramatic rebound of the domestic equity markets. During 2006, major A-share indices were up by more than 100 per cent. The realised return of the NSSF during the first three-quarters was reportedly over 6 per cent, more than 100 per cent of which was attributed to equity investments. ${ }^{9}$

Strategic investments in Pre-IPO shares One of the more eye-catching moves made by the NSSF are pre-IPO strategic investments into 


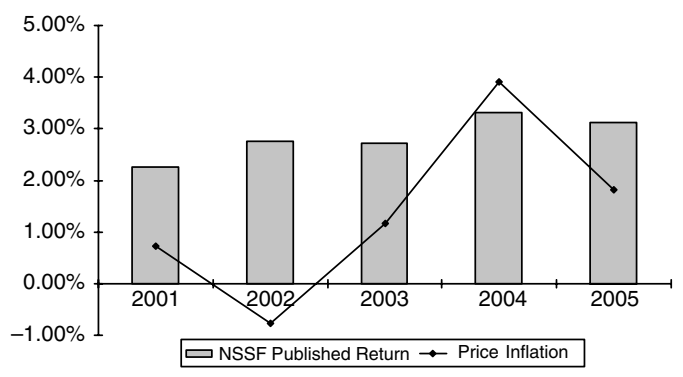

Figure 3: NSSF return vs price inflation. Source: NSSF and IMF

large Chinese companies, especially the banks, at extremely attractive prices. Given that IPO prices tend to be significantly higher than the prices paid by pre-IPO private equity investors, these investments have generated massive windfall profits for the NSSF (although only when shares are sold will the profits be realised). As the NSSF is a passive investor and could add only limited value in improving the operation or governance of the banks, allowing the NSSF to become a pre-IPO investor and make some 'risk-free' profits is a conscious political and economic decision by the Chinese government to help the NSSF boost its returns as quickly as possible.

One of the earliest investments of this kind occurred in June 2004, when the Bank of Communications (BoCom), one of China's smaller yet more profitable state-owned banks, restructured in preparation for a Hong Kong listing. The NSSF invested RMB10bn (US $\$ 1.2 \mathrm{bn}$ ) in BoCom as a strategic investor, and became the third largest owner of BoCom after the MoF and HSBC. In July 2005, BoCom shares were listed in Hong Kong at a price 42 per cent higher than that paid by the NSSF, netting it with a handsome (although unrealised) return of over RMB4.2bn (US $\$ 0.5 \mathrm{bn}){ }^{10}$

Encouraged by this result, the NSSF made similar pre-IPO investments in bigger banks, including RMB10bn (US\$1.2bn) in the Bank of China $(\mathrm{BoC})$ and same amount ${ }^{11}$ in the Industrial and Commercial Bank of China (ICBC), both at extremely attractive prices. The successful Hong Kong listings of BoC in June and ICBC in October of 2006 benefited the NSSF with immediate unrealised returns totaling approximately RMB30.5bn (US\$3.9bn). ${ }^{12}$ Given that all three bank stocks have performed well post-IPO, and assuming that the shares have not yet been sold because of a lock-up period, the cumulative unrealised gains for the NSSF in these three banks would approximate US $\$ 7$ bn by October 2006.

Not all parties agree with the NSSF's aggressive investments in the Chinese banks. Some question whether it is wise for the NSSF to allocate RMB30bn (US $\$ 3.8$ bn), or close to 15 per cent of its book assets, into three Chinese banks. ${ }^{13}$ The NSSF, however, argues that these pre-IPO investments are virtually risk free. To reduce concentration risks, the NSSF has indicated that it will temporarily refrain from additional investments into the banking and finance sector and will turn to industrial companies instead.

\section{Overseas investments}

The NSSF has long lobbied for government approval to allow it to invest overseas, as in fact it started to accumulate significant amounts of foreign capital from the overseas listing of Chinese SOEs. The NSSF hoped that rather than having to convert all such foreign exchange to $\mathrm{RMB}$ and then remit back to Beijing, it could instead keep the cash in foreign currencies and invest this in foreign securities. This would not only lead to better diversification, but also promised higher returns as the domestic equity market seemed to be stuck in a prolonged slump and interest rates were very low.

In October 2003, Xiang Huaicheng, chairman of the NSSF, formally submitted an overseas investment proposal to the MoF, MoLSS, SAFE and CSRC as well as the PBoC. ${ }^{14}$ The approval process, however, proved to be long and arduous as it involved negotiating with various government agencies, each with its own concerns and priorities. Particularly, the CSRC, the regulatory body that oversees China's securities markets, was worried that allowing the NSSF to invest overseas would reduce investors' confidence in the domestic stock market, which was at the time one of the worst performing in the world. While in early 2004, a decision was made 'in 
Table 2: NSSF overseas mandates

\begin{tabular}{llll}
\hline Mandate & Index & $\begin{array}{l}\text { Target net-of-fees excess } \\
\text { return p.a. (bps) }\end{array}$ & $\begin{array}{l}\text { Tracking error p.a. } \\
\text { (bps) }\end{array}$ \\
\hline Global (ex-US) equities & MSCI World (ex USA) & +200 & Within 800 \\
US equities & S\&P 500 & +50 & Within 200 \\
Hong Kong equities & FTSE/Xinhua Hong Kong & +300 & Within 800 \\
Global fixed income & Lehman Brothers Global Aggregate & +100 & Within 200 \\
Cash & Bond & 0 & NA \\
\hline
\end{tabular}

Source: Notice regarding selection and appointment of overseas managers, 29th April, 2006, NSSF website.

principle' to allow the NSSF to make investments overseas, ${ }^{15}$ the NSSF had to wait for two more years before an implementation guideline was issued in March 2006. By this time, the situation had changed - the domestic equity market had already staged a convincing rebound, the massive foreign exchange reserves in China has led to significant pressure on the RMB to revalue, and new regulations allowing Chinese banks and fund managers to seek client money to invest abroad were imminent. The NSSF at this point had accumulated approximately US $\$ 1.6 \mathrm{bn}$ or approximately 6 per cent of its total assets in foreign exchange. ${ }^{16}$

Once it obtained the regulatory green light, the NSSF acted quickly. It announced that it would invest between US $\$ 500 \mathrm{~m}$ and US $\$ 800 \mathrm{~m}$ overseas by the end of 2006. In April it posted on its website a bidding invitation (in Chinese) for five different overseas mandates, specifying eligibility criteria for bidding firms, target returns against benchmark indices and tracking errors, plus a step-by-step review and selection process. In addition, Mercer, an international investment consultancy, was appointed as the adviser to the manager selection process.

Details of the mandates are summarised in Table 2.

The invitation to bid generated much enthusiasm among foreign managers. Many fund managers believe that although fees would be modest, winning a first overseas mandate from China's no. 1 institutional investor would bring them credibility and long-term strategic value in the potentially huge Chinese asset management industry. By the end of June 2006 some 106 managers, a who's who list of the international
Table 3: NSSF Overseas Mandate Winners

\begin{tabular}{ll}
\hline Mandate & Manager(s) \\
\hline Hong Kong equities & Allianz; Invesco; UBS/CICC \\
Global (Ex-US) equities & AllianceBernstein; AXA \\
& Rosenberg; State Street \\
US equities & JanusINTECH; T. Rowe Price \\
Global fixed income & AllianceBernstein; Blackrock; \\
Cash & PIMCO \\
\hline
\end{tabular}

Source: NSSF

investment world, submitted expressions of interest. In August the NSSF short-listed 25 managers for further review including faceto-face interviews with the NSSF Expert Appraisal Committee. The Expert Appraisal Committee was made up of three NSSF officials, as well as four independent Chinese and foreign experts led by Mr Antony Leung, former Financial Secretary of Hong Kong. In September, the interviews were concluded and the winners were identified. The list of winners was published in November (Table 3). ${ }^{17}$

Separately, the NSSF has announced that it has selected Citibank and Northern Trust as global custodians for its overseas investments. ${ }^{18}$

The international fund managers have in general been impressed (and perhaps somewhat surprised) by the level of professionalism demonstrated in the selection process. Many commented that the process appeared fair and without political interference. It seems that the NSSF, in its selection of overseas managers, has set a new higher standard of governance for other Chinese government agencies and for China's fund management industry generally. 


\section{Controversies and governance issues}

The NSSF has made significant achievements since its inception in 2000. Its increasing sophistication and its willingness to learn from international best practices have impressed many. Several challenges, however, remain - some of which are design issues in nature and reflect ambiguities among its founding agencies at the time of establishment. These issues, unless properly addressed, may lead to potential governance problems.

\section{Objectives and purposes}

According to the NSSF website, 'the NSSF aims to be a solution to the problem of ageing and serves as a strategic reserve fund accumulated by central government to support future social security needs'. Beyond this broad mandate, however, nothing is known about how exactly the NSSF fits into China's pension system. For instance, it is unclear whether the NSSF covers all aspects of social security (pensions, medical insurance, unemployment insurance, workers' compensation, maternity benefits and poverty alleviation) or focuses purely on pension needs. Some Western media describe the NSSF as 'China's national welfare fund' while most domestic media refer to the NSSF vaguely as 'China's national old age pension fund'.

The words 'strategic reserve' seem to imply that the Fund will be used only in emergency situations such as bailing-out provincial-level pension system failures when called upon - yet this guarantee function is not clearly specified and interestingly, when Liaoning, Jilin and Heilongiiang provinces faced pension difficulties, the central government used fiscal policy, that is, reductions of tax obligations by the provinces to the central government, to help them tide over the difficulties. The NSSF funds were not actually applied. It is still completely unclear under what circumstances will the NSSF funds be applied, either by way of loan, grant or subsidy.

The lack of clearly defined objectives and purposes would certainly generate false expectations among various claimant groups in the future; and could also potentially lead to misuse of the funds especially under political influence. The State Council will need to think very carefully and clearly define the objectives and the purposes of the NSSF as soon as practical.

\section{Legal structure}

Another weakness of the NSSF is that it is not established under trust. Although the NCSSF is sometimes described as 'acting like trustee', it is nevertheless not a trustee and not bound by China's Trust Law. Consequently, there are no defined beneficiaries for the Fund, and no guidelines regarding distribution of benefits. Fiduciary duties, a key concept of Trust Law, is therefore not binding on the NCSSF.

One reason for the NSSF not being set up under trust may be that the concept of trust is relatively new in China, as the country's Trust Law did not come into effect until October 2001. In contrast, China's more recent regulations on Enterprise Annuities (Pillar II voluntary corporate pension plans) released in 2004 specifies that EAs must be managed under Trust. By comparison the NSSF legal structure is lagging behind.

Some experts argue that as an alternative to a trust structure, which could achieve the same intended effect, the State Council could pass a regulation that clearly defines the NCSSF's 'trustlike' nature including fiduciary duties as well as clearly defining beneficiaries and their rights in written format. This would essentially specify clearly in legal format the key components of a trust structure, including beneficiaries and fiduciary duties, without actually applying Trust Law which remains unfamiliar to most Chinese officials.

Either way, to place the NSSF under trust or a trust-like legal framework should generally improve the long-term security of the NSSF.

\section{Composition of the NCSSF}

The NCSSF is led by a 17-member board including one chairman and three vice chairmen. The chairman and vice chairmen are all directly appointed by the State Council, and the remaining 13 directors comprise either current or former senior government officials appointed 
rather than elected to their positions. No external independent director is included in the board.

Internationally, some of the best-run state pension funds have much more transparent and democratic governance structures, which could serve as examples for the NCSSF. For instance, CalPERS, which manages over US $\$ 200 \mathrm{bn}$ of assets for 1.4 million public employees and retirees in California, is governed by a 13member Board of Administrators including six elected member representatives. Information such as board meeting agenda and schedules, election schedules and candidate eligibility criteria and the election process is all published and open to public scrutiny. ${ }^{19}$

The board structure of the NCSSF also contrasts with that of listed Chinese companies. The CSRC issued a guideline in August 2001, which encouraged listed companies to have at least one-third of their board as independent directors. ${ }^{20}$ Some of the more forward-thinking Chinese companies, such as BoC and BoCom (both invested in by the NSSF), have already implemented the independent director system and have invited senior international experts to be independent board members.

The inclusion of independent directors in the NCSSF will help the NCSSF to better address any potential agency problems. It will also help to ensure that the NCSSF resist any political influence that could compromise the purposes of the Fund. If international experts are included, the NCSSF could also benefit from their insights and experience in other markets and improve the overall strategic thinking and decision making at the Fund.

\section{Disclosure and transparency}

The disclosure and transparency of operations and investments results at the NSSF also needs improvement. Currently, data on operations and investment returns are published only once a year in the form of an annual report by the NCSSF. The annual reports tend to be extremely abbreviated - the 2005 Annual Report contained only nine pages in total. Furthermore, it seems that the accounts included in the historical annual reports are not audited.
In addition, a historical cost rather than markto-market accounting method is used for reporting, leading to concerns about the veracity of the reported results. In line with best international practice, the Fund should disclose all investments at market value.

As the NSSF starts to appoint overseas fund managers with its international equity and bond mandates, it may gradually adopt a mark-tomarket approach, perhaps starting first with its international portfolios. The adoption of international standard accounting and auditing processes should bring more transparency, objectivity and accountability to the operations of the NSSF, and should enhance its governance overall.

\section{Conclusions}

The NSSF has made impressive progress in terms of its asset base, sophistication in operations and management, as well as its pioneering efforts in international diversification. It has become China's no. 1 institutional investor not only in size, but also in stature and influence in China's institutional fund industry. Design and governance issues, however, remain, which require attention and resolution. The NSSF will need to address these issues in a proactive manner relatively soon to ensure that its long-term strategic goals and priorities are not compromised.

\section{References and Notes}

1 UN Population Division. World Population Prospects, the 2004 Revision. http://esa.un.org/unpp/.

2 A more detailed account of the Chinese pension reforms can be found in Pension Funds in China: a New Look, by Stuart Leckie and Yasue Pai. ISI Publications, Hong Kong, 2005.

3 Sin, Y. (2005) The World Bank. Working paper series on China: Pension liabilities and reform options for old age insurance. Paper no. 2005-1. May.

4 The information and data presented in sections The establishment and the administration of NSSF, NSSF sources of assets and The investments of NSSF, unless noted otherwise, are obtained from the NSSF website: www.ssf.gov.cn; or from the annual reports of the NSSF, which can be downloaded from the website (mainly in Chinese).

5 The Preliminary Rules on the Administration of the Investments of the National Social Security Fund. Jointly issued by MoF and MoLSS, Dec. 2001

6 At the time this report is written, the Chinese government is considering to re-introduce the rule that a portion of domestic SOE IPO proceeds or shares be allocated to the NSSF. 
7 Annual investment return figures contained in this section are published in the NSSF annual reports. They are based on historical cost accounting rather than mark-to-market accounting and may not therefore represent the true investment performance of the Fund. Hence, volatility in the returns is likely to be significantly understated.

8 Song, X. (2006) 'Rising stock market boosts NSSF investment returns', First Financial and Economic Daily, 20 October.

9 Ibid.

10 Bank of Communications IPO Prospectus and IPO Allotment Result, June 2005.

11 The Chinese media has widely reported that the NSSF's investment in the ICBC was RMB18bn (US\$2.25bn). According to the ICBC IPO Prospectus published in October 2006 however, of the RMB18bn paid to the ICBC by the NSSF, RMB8bn was paid on behalf of MoF with the NSSF acting as a custodian to the underlying shares and the MoF enjoying the economic rights of the underlying shares, pursuant to a custody agreement between the two parties. Therefore, the investment made 'directly' by the NSSF in the ICBC should only be RMB10bn (US\$1.25bn).
12 Based on information obtained from $\mathrm{BoC}$ and ICBCs IPO Prospectuses and IPO Allotment Results in May and October 2006, respectively.

13 Indeed, at current market prices the value of the three bank shareholdings is estimated at well over 30 per cent of total NSSF assets

14 Liu, X. (2004) 'Xiang Huaicheng's ambitious plan: The NSSF to become the first QDII'. 21st Century Finance, 23 October.

15 Zhao, X. (2004) 'The state council approves the NSSF to invest abroad - A special case rather than a QDII', Caijing Magazine, 8 March.

16 General press release for the Second Session of the Second NCSSF Convention, March 2006, published on the NSSF website.

17 Huo, K. (2006) 'Overseas fund managers list approved by the NSSF', First Financial and Economic Daily, 11 September.

18 Anderlini, J. (2006) 'Pension fund picks Citibank, northern trust as custodian', South China Morning Post, 26 July.

19 CalPERS. website: www.calpers.ca.gov.

20 'Guidelines regarding the establishment of independent director system at listed companies', the CSRC, August 2001. 